\title{
Dispersive Liquid-Liquid Microextraction Procedure for the Determination of Palladium by Flame Atomic Absorption Spectroscopy
}

\author{
Şerife Saçmacı, * Şenol Kartal and Sevilay Dural \\ Department of Chemistry, Faculty of Sciences, Erciyes University, TR-38039, Kayseri, Turkey
}

Um novo método de pré-concentração usando microextração líquido-líquido dispersiva (DLLME), foi desenvolvido para a determinação de paládio. Na abordagem proposta, foi utilizado 2,2'-furildioxima como agente quelante, enquanto clorofórmio e metanol foram usados como solvente de extração e solvente dispersivo, respectivamente. Muitos fatores que influenciam a eficiência da microextração, como tipo e quantidade dos solventes de extração e dispersivo, acidez da solução da amostra, concentração do agente quelante e tempo de centrifugação foram investigados e as condições otimizadas da microextração foram estabelecidas. Sob condições ótimas, o fator de pré-concentração deste método para paládio foi de 250 . O limite de detecção para paládio foi $0,04 \mu \mathrm{g} \mathrm{L}^{-1}(3 \mathrm{~s})$, e o desvio padrão relativo $(\mathrm{RSD})$ foi $1,1 \%(\mathrm{n}=8)$ para uma solução de $4 \mu \mathrm{g} \mathrm{L}^{-1}$. A precisão do método foi obtida pela análise de material de referência certificado (CDN-PGMS-10). O método desenvolvido foi aplicado com sucesso na determinação de paládio em conversor catalítico, lodo anódico, sedimentos de estrada e amostras de água.

A new dispersive liquid-liquid microextraction (DLLME) preconcentration method was developed for the determination of palladium. In the proposed approach, 2,2'-furyldioxime was used as chelating agent, while chloroform and methanol were used as extraction and dispersive solvents, respectively. Several factors that influence the microextraction efficiency, such as type and amount of extraction and dispersive solvents, acidity of sample solution, concentration of the chelating agent, and centrifugation time were investigated and the optimized microextraction conditions were established. Under the optimum conditions, the preconcentration factor of this method for palladium was reached at 250. The limit of detection for palladium was $0.04 \mu \mathrm{g} \mathrm{L} \mathrm{L}^{-1}(3 \mathrm{~s})$, and the relative standard deviation $(\mathrm{RSD})$ was $1.1 \%(\mathrm{n}=8)$ at $4 \mu \mathrm{g} \mathrm{\textrm {L } ^ { - 1 }}$ level. The accuracy of the method was performed by analysis of the certified standard reference material (CDN-PGMS-10). The developed method was applied successfully to the determination of palladium in the catalytic converter, anode slime, road sediment and water samples.

Keywords: palladium, dispersive liquid-liquid microextraction, 2,2'-furyldioxime, atomic absorption spectrometry

\section{Introduction}

Palladium is an element of increasing importance in today's industries. The annual production of palladium is estimated to be 195 tonnes; the majority of this is used in autocatalysts (55\%), with other uses including electronics $(16 \%)$, jewellery $(11 \%)$, dental $(8 \%)$, investment $(5 \%)$ and chemical (4\%). ${ }^{1}$ It is also used for the purification of hydrogen gas. ${ }^{2}$ Elevated level of Pd compared to geochemical background has been found in airborne particulate matter, road dust, soil and grass. ${ }^{3-6}$ Although the benefits of this valuable element are undisputable,

*e-mail: sacmaci@erciyes.edu.tr increasing use of it results in being released into the atmosphere leading to contamination of food and waterbodies which finally lead to bioaccumulation in the living organisms through diverse pathways. ${ }^{7}$ However palladium has no biological role, but all palladium compounds should be regarded as highly toxic and carcinogenic, causing asthma, allergy, rhino-conjunctivitis, etc. ${ }^{8}$

Development of analytical methods for the accurate and precise determination of traces of palladium is meaningful for quality control of industrial products, environmental monitoring as well as palladium ore exploration. In the determination of traces of palladium in industrial materials and environmental samples, serious interferences often occur owing to matrix components. ${ }^{9,10}$ Modern techniques 
such as inductively coupled plasma-atomic emission spectrometry, ${ }^{11}$ atomic absorption spectrometry, ${ }^{10,12}$ spectrophotometry, ${ }^{13,14}$ and complexometry, ${ }^{15,16}$ etc., have been widely used for the determination of palladium. Therefore, several preconcentration methods such as coprecipitation, ${ }^{17}$ liquid-liquid extraction (LLE), ${ }^{18,19}$ solid-phase extraction (SPE) ${ }^{20}$ sorption and ion-exchange ${ }^{21}$ and cloud point extraction $(\mathrm{CPE})^{22,23}$ have been reported for the separation and preconcentration of palladium ions, but the disadvantages such as time-consuming, unsatisfactory enrichment factors, large organic solvents and secondary wastes, have limited their applications.

Modern trends in analytical chemistry are towards the simplification and miniaturization of sample preparation procedures, as well as the minimization of solvent and reagent consumption. ${ }^{23,24}$ Unconventional liquid-liquid extraction (LLE) methodologies have been arisen like: single drop microextraction (SDME) ${ }^{25}$ wetting film extraction (WFE) ${ }^{26}$ cloud point extraction (CPE ${ }^{27}$ and dispersive liquid-liquid microextraction (DLLME). ${ }^{28-31}$ Simplicity, rapidity, low sample volume, low cost, high recovery and enrichment factors are some advantages of DLLME and the technique has been applied for the determination of trace organic pollutants and metal ions in environmental samples. ${ }^{32}$

DLLME is a miniaturized sample pretreatment technique based on a ternary component solvent system where the dispersion of fine droplets of the extraction solvent is accomplished within the aqueous phase. ${ }^{33,34}$ Consequently, vigorous shaking or mixing is not necessary. The principal advantage of DLLME is that the surface area between extraction solvent and aqueous sample initially is infinitely large, thus the equilibrium state is achieved quickly and the extraction time is very short. However, when DLLME is performed in manual mode, is limited to a small number of extraction solvents, since it is critical that one of the extraction solvents be heavier than water (i.e., carbon tetrachloride, chlorobenzene and chloroform) and the other one lighter than water (i.e., cyclohexane, $n$-hexane, isopropyl ether, toluene, o-xylene and naphtha), in order to form stable cloudy solution capable of being separated at the bottom and/or at the top of the aqueous phase by centrifuging. ${ }^{35-41}$ In addition, the phase separation with centrifugation is a time consuming procedure including inherent problems of low precision. ${ }^{10}$

In this study, we developed a new dispersive liquidliquid microextraction (DLLME) procedure combined with FAAS by applying a microsample introduction system for the final measurement of Pd(II). By using this method, low volumes of extraction solvent $(100 \mu \mathrm{L})$ can be used without loss of sensitivity. The aim of this study was to exhibit the application of the mentioned technique for rapid determination of palladium at trace concentrations $\left(\mu \mathrm{g} \mathrm{L}^{-1}\right.$ and/or $\mu \mathrm{g} \mathrm{g}^{-1}$ levels). The factors affecting the efficiency of DLLME system were studied thoroughly. The developed method was successfully applied to catalytic converter, anode slime, road sediment, water samples and certified reference material.

\section{Experimental}

Instrument

A PerkinElmer (Norwalk, CT, USA) model AAnalyst 800 flame atomic absorption spectrometer equipped with a deuterium background correction system and an air-acetylene burner was used for the determination of palladium. The wavelength used for palladium was $244.8 \mathrm{~nm}$. Spectral bandwidth of $0.2 \mathrm{~nm}$, acetylene flow rate of $1.4 \mathrm{~L} \mathrm{~min}^{-1}$, and nebulizer flow rate of $10 \mathrm{~mL} \mathrm{~min}^{-1}$ were conventional working parameters. A Consort model C533 pH meter combined with a glass-electrode and an MLTW-54 model centrifuge were employed throughout measurements.

\section{Reagents and standard solutions}

All reagents used were of the highest available purity and at least analytical reagent grade (Merck, Darmstadt, Germany). Deionized ultra pure water was used for the preparation of the solutions. A stock standard solution containing $100 \mathrm{mg} \mathrm{L}^{-1} \mathrm{Pd}$ (II) was made by dissolving $50 \mathrm{mg}$ of elemental palladium in $4 \mathrm{~mL}$ of aqua regia and subsequent dilution with $1.0 \mathrm{~mol} \mathrm{~L}^{-1} \mathrm{HCl}$ to $500 \mathrm{~mL}$. Working standard solutions were prepared by appropriate stepwise dilution of the stock standard solution with $0.1 \mathrm{~mol} \mathrm{~L}^{-1} \mathrm{HNO}_{3}$ just before use. The $0.1 \%(\mathrm{~m} / \mathrm{v}) 2,2$ '-furyldioxime solution was prepared by dissolving $0.1 \mathrm{~g}$ of the reagent in $100 \mathrm{~mL}$ of methanol. The glassware used was cleaned by soaking overnight in diluted $\mathrm{HNO}_{3}(1: 5, \mathrm{v} / \mathrm{v})$, and then rinsed with deionized water several times.

\section{Preparation of samples}

The CRM used was obtained from CDN Resource Laboratories Ltd., British Columbia, Canada. The ore was supplied by Stillwater Mining Corporation from the Stillwater Complex in Montana, USA, and has a palladium concentration of $10.99 \mathrm{mg}$ per $\mathrm{kg}$. Portions of $0.1 \mathrm{~g}$ of CDN-PGMS-10 standard reference material were transferred into PTFE beakers; $10 \mathrm{~mL}$ of concentrated $\mathrm{HNO}_{3}$ and $3 \mathrm{~mL}$ of $\mathrm{H}_{2} \mathrm{O}_{2}$ were added and heated until the 
solution becomes transparent, and then it was continued to heating to near dryness. The residue was dissolved in $0.1 \mathrm{~mol} \mathrm{~L}^{-1} \mathrm{HNO}_{3}$ and made up to $25 \mathrm{~mL}$, and then the preconcentration procedure given above was applied to the sample solutions.

A $0.1 \mathrm{~g}$ crushed and ground portion of the catalytic converter sample obtained from Organized Industrial Distinct of Kayseri, Turkey, was weighed into a beaker. In order to decompose, $20 \mathrm{~mL}$ of aqua regia was added to the beaker and the mixture was heated until to almost dryness. Then, $10 \mathrm{~mL}$ of aqua regia was added again to the residue and the mixture was evaporated to dryness. Finally, the residue was taken into solution using $0.1 \mathrm{~mol} \mathrm{~L}^{-1} \mathrm{HNO}_{3}$. The insoluble part of the sample was filtered through a blue ribbon filter paper. The volume of the filtrate was completed to $25 \mathrm{~mL}$ with $0.1 \mathrm{~mol} \mathrm{~L}^{-1} \mathrm{HNO}_{3}$. An aliquot of $100 \mu \mathrm{L}$ of this solution was diluted to $25 \mathrm{~mL}$ and then the preconcentration procedure was applied to the sample solutions. Analyses for blanks were carried out in the same way. The determination of $\mathrm{Pd}(\mathrm{II})$ ions in the final measurement solution was performed by FAAS.

The other two solid samples, the anode slime and the road sediment, have been treated as described above in the sample preparation procedure for the catalytic converter before their analysis without applying the dilution step. The anode slime samples were obtained from a copper wire plant located in the Organized Industrial Distinct of Kayseri, and the road sediment samples were collected in roadside sediments in streets of Nevşehir, Turkey.

\section{Dispersive liquid-liquid microextraction procedure}

Under the optimized experimental conditions, aliquots of $10 \mathrm{~mL}$ of sample solution containing $\mathrm{Pd}$ in $0.1 \mathrm{~mol} \mathrm{~L}^{-1}$ $\mathrm{HNO}_{3}$ were placed into 50-mL screw cap glass test tubes with conic bottom. A mixture of $0.4 \mathrm{~mL}$ of methanol (disperser solvent), $0.1 \mathrm{~mL}$ of $0.1 \%$ 2,2'-furyldioxime solution (chelating agent) in methanol and $100 \mu \mathrm{L}$ of chloroform (extraction solvent) was rapidly injected into the sample solution by using a microsyringe. A cloudy solution (water, methanol, and chloroform) was formed in the test tube. In this step, $\mathrm{Pd}(\mathrm{II})$ reacted with 2,2'-furyldioxime and the formed complex was extracted into the fine droplets of chloroform. Then, the solution was centrifuged at $3000 \mathrm{rpm}$ for $3 \mathrm{~min}$, and the dispersed fine droplets of chloroform were deposited at the bottom of conical test tube. An aliquot of $100 \mu \mathrm{L}$ of the sedimented phase was removed using a microsyringe. In order to determine the palladium in the chloroform phase, a $25 \mu \mathrm{L}$ aliquot of this solution was introduced to the nebulizer of the flame atomic absorption spectrometer by using the micro injection method. ${ }^{42}$ The palladium signals were measured in the peak area mode utilizing the instrument software. The calibration graph was prepared against aqueous standards by submitting to the same DLLME procedure. Blank determinations were carried out as parallel to the measurements made for sample and calibration standards.

\section{Results and Discussion}

To obtain high enrichment factors, the effects of different parameters such as acidity, types and volumes of extraction and dispersive solvents, concentration of chelating agent, and amounts of coexisting ions, were optimized.

\section{Effect of acidity}

Separation of metal ions by DLLME technique involves prior complex formation with sufficient hydrophobicity to be extracted into the extraction phase, thus, obtaining the desired preconcentration. Acidity of the sample solution plays a unique role on the formation of the metal-chelate complex and subsequent extraction. The reagent, 2,2'-furyldioxime, is particularly useful during the analysis of palladium, since complete precipitation is achieved even from solutions of strong mineral acids. ${ }^{43}$ So, in order to evaluate the effect of acidity on the extraction of palladium ions, sample solutions were acidified from 0.01 to $4.0 \mathrm{~mol} \mathrm{~L}^{-1}$ with $\mathrm{HNO}_{3}$ and/or $\mathrm{HCl}$, and processed according to the recommended procedure. As can be seen from Figure 1, the results showed that the recovery is almost constant by increasing acidity from 0.01 to $3 \mathrm{~mol} \mathrm{~L}^{-1}$ $\mathrm{HNO}_{3}$. In the light of these results, the optimum acidity was selected as $0.1 \mathrm{~mol} \mathrm{~L}^{-1} \mathrm{HNO}_{3}$ for further experiments. The sample solutions acidified with $\mathrm{HCl}$ did not gave quantitative results, probably due to the formation of stable chloro complexes between Pd(II) and chloride ions,

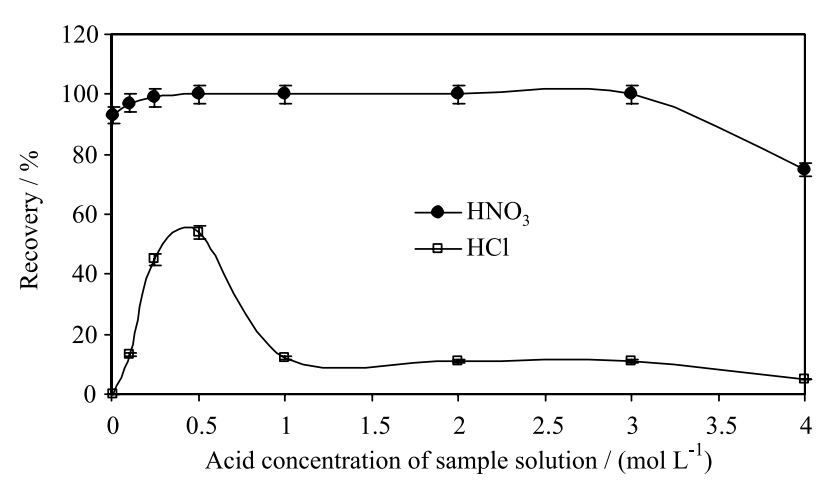

Figure 1. Effect of acid concentration of the sample solution on the Pd(II) signals. Type and amount of extraction solvent: $100 \mu \mathrm{L}$ of $\mathrm{CHCl}_{3}$, type and amount of disperser solvent: $0.4 \mathrm{~mL}$ of methanol, amount of 2,2'-furyldioxime: $0.1 \mathrm{~mL}$ of $0.1 \%$, centrifugation time and rate: $3 \mathrm{~min}$ and $3000 \mathrm{rpm}$. 
because the dissociation constant of the chloropalladite anion, $\mathrm{PdCl}_{4}^{2-}$, is $6 \times 10^{-14} .{ }^{44}$ Consequently, the formation constant of $\mathrm{PdCl}_{4}^{2-}$ complex is probably higher than that of the Pd(II)-2,2'-furyldioxime complex.

\section{Effect of type and amount of extraction and disperser solvents}

The type of extraction solvent used in DLLME procedure is selected on the basis of higher density rather than water, extraction capability of interested compounds, and low solubility in water for efficient microextraction. Chloroform $\left(\mathrm{CHCl}_{3}\right)$ and carbon tetrachloride $\left(\mathrm{CCl}_{4}\right)$ were tested as extraction solvents $(100 \mu \mathrm{L})$ using methanol and/or ethanol as disperser solvent (about $0.4 \mathrm{~mL}$ ). Also, $0.1 \mathrm{~mL}$ of $0.1 \%$ 2,2'-furyldioxime in methanol was used to achieve about $100 \mu \mathrm{L}$ volume of the sedimented phase. When $\mathrm{CCl}_{4}$ was used as extraction solvent, an unstable cloudy solution was obtained and it was difficult to separate the sedimented phase from this solution. However, $\mathrm{CHCl}_{3}$ and methanol pair gave the best results and they were chosen as the extraction and disperser solvents, respectively, for the further experiments (see Figure 2).

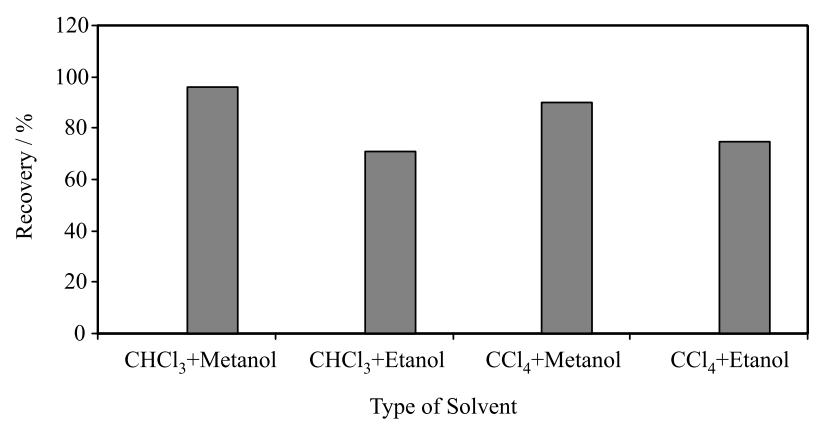

Figure 2. Effect of type of the solvents on the recovery of Pd(II) signals $(\mathrm{n}=3)$. Acidity: $0.1 \mathrm{~mol} \mathrm{~L}^{-1} \mathrm{HNO}_{3}$, amount of extraction solvent: $100 \mu \mathrm{L}$, amount of disperser solvent: $0.4 \mathrm{~mL}$, amount of 2,2'-furyldioxime: $0.1 \mathrm{~mL}$ of $0.1 \%$, centrifugation time and rate: $3 \mathrm{~min}$ and $3000 \mathrm{rpm}$.

In order to examine the effect of volume of the extraction solvent, different volumes of $\mathrm{CHCl}_{3}$ changing from 50 to $600 \mu \mathrm{L}$ were subjected to the same DLLME procedure. By increasing the volume of $\mathrm{CHCl}_{3}$ from 50 to $100 \mu \mathrm{L}$, the recovery increased sharply and then nearly constantly up to $400 \mu \mathrm{L}$ of $\mathrm{CHCl}_{3}$ (see Figure 3). Thereby, $100 \mu \mathrm{L} \mathrm{CHCl}_{3}$ was chosen as optimal volume of the extraction solvent in the subsequent experiments. The preconcentration factor for the proposed method was found to be 250 .

For the DLLME method, dispersive solvent should be miscible with both water and the extraction solvent. In addition, the type of the disperser solvent directly influences the viscosity of the binary mixture. Thus, disperser solvents can control droplet producing and extraction efficiency.

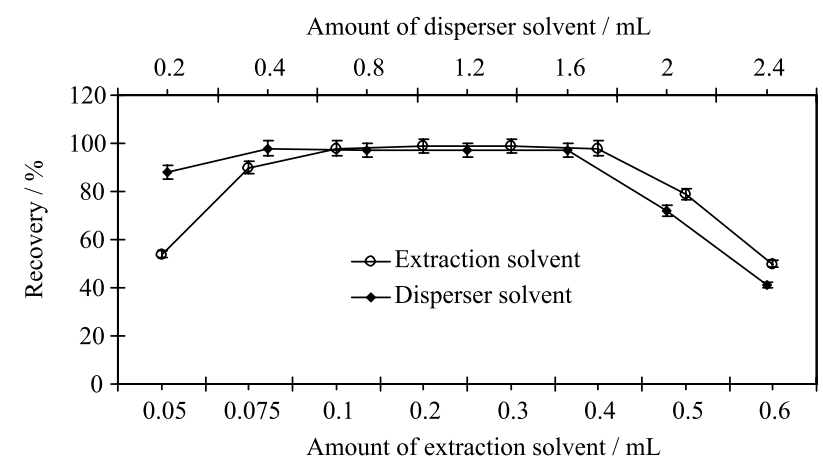

Figure 3. Effect of the amount of extraction solvent on the $\mathrm{Pd}(\mathrm{II})$ signals. Acidity: $0.1 \mathrm{~mol} \mathrm{~L}^{-1} \mathrm{HNO}_{3}$, amount of 2,2'-furyldioxime: $0.1 \mathrm{~mL}$ of $0.1 \%$, centrifugation time and rate: $3 \mathrm{~min}$ and $3000 \mathrm{rpm}$.

The effect of the amount of methanol as the disperser solvent, containing $100 \mu \mathrm{L}$ of $\mathrm{CHCl}_{3}$ as the extraction solvent and $0.1 \mathrm{~mL}$ of $0.1 \% 2,2$ '-furyldioxime in methanol as complexing agent, on the extraction efficiency of the method, was investigated using $10 \mathrm{~mL}$ of sample solution. To obtain the optimum volume of methanol, a series of experiments were performed with different amounts of methanol changing from 0.2 to $2.4 \mathrm{~mL}$. The results showed that the analytical signal increased slowly up to $0.4 \mathrm{~mL}$ and reached to maximum value with increasing amount of methanol. Small amounts of methanol less than $0.4 \mathrm{~mL}$ could not show enough dispersive effect to form a cloudy solution. On the contrary, at high volumes, the solubility of the complex in water increased by the increasing volume of methanol. Finally, 0.4 of mL methanol was chosen as the optimum volume of the disperser solvent (see Figure 3).

\section{Effect of the amount of 2,2'-furyldioxime}

The effect of the amount of $0.1 \%(\mathrm{~m} / \mathrm{v}) 2,2$ '-furyldioxime solution on the extraction efficiency of the DLLME method for the determination of $\mathrm{Pd}(\mathrm{II})$ was investigated for the amounts of the reagent varying from 0.025 to $0.4 \mathrm{~mL}$. The results showed that the Pd(II) signals sharply increased up to $0.05 \mathrm{~mL}$ and slowly to $0.1 \mathrm{~mL}$ of 2,2 '-furyldioxime and then remained almost constant up to $0.3 \mathrm{~mL}$ of the reagent. As can be seen from Figure 4, the optimum amount of the reagent was $0.1 \mathrm{~mL}$ and this amount of the ligand solution was used in the subsequent experiments.

\section{Effect of the centrifugation rate and time}

One of the most important parameters for the DLLME procedures was centrifugation rate. For this purpose, a series of experiments were made at different centrifugation rates varying from 1000 to $4000 \mathrm{rpm}$ for $3 \mathrm{~min}$. The absorbance sharply increased up to the centrifugation rate of $2500 \mathrm{rpm}$, 


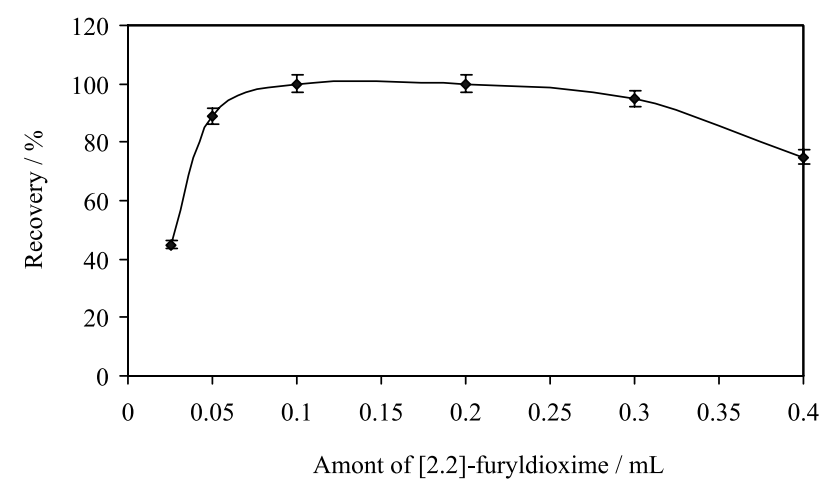

Figure 4. Effect of the amount of 2,2'-furyldioxime $(0.1 \%, \mathrm{~m} / \mathrm{v})$ on the Pd(II) signals. Acidity: $0.1 \mathrm{~mol} \mathrm{~L}^{-1} \mathrm{HNO}_{3}$, type and amount of extraction solvent: $100 \mu \mathrm{L}$ of $\mathrm{CHCl}_{3}$, type and amount of disperser solvent: $0.4 \mathrm{~mL}$ of methanol, centrifugation time and rate: $3 \mathrm{~min}$ and $3000 \mathrm{rpm}$.

a slow increase was observed up to $3000 \mathrm{rpm}$ and then remained almost constant. A decrease was observed over the centrifuging rate of $3500 \mathrm{rpm}$. As the optimal centrifugation rate the $3000 \mathrm{rpm}$ was selected (see Figure 5).

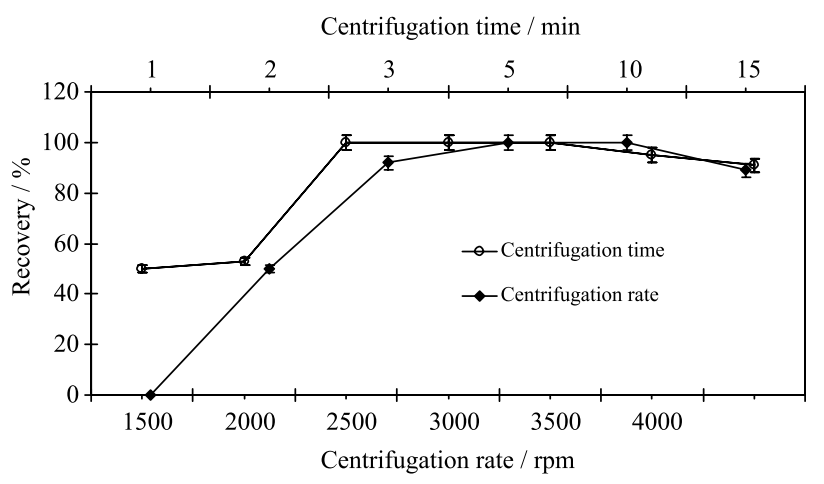

Figure 5. Effect of the centrifugation rate on the Pd(II) signals. Acidity: $0.1 \mathrm{~mol} \mathrm{~L}^{-1} \mathrm{HNO}_{3}$, type and amount of extraction solvent: $100 \mu \mathrm{L}$ of $\mathrm{CHCl}_{3}$, type and amount of disperser solvent: $0.4 \mathrm{~mL}$ of methanol, amount of 2,2'-furyldioxime: $0.1 \mathrm{~mL}$ of $0.1 \%$.

Another important parameter is the centrifugation time for microextraction procedures. In order to get the best centrifugation time, the experiments were performed in the range of 1-15 min under the optimized conditions. The results showed that the centrifugation time had a significant influence on the signal of $\mathrm{Pd}(\mathrm{II})$. The best results were obtained between 3 and $10 \mathrm{~min}$ of centrifugation time. The $\operatorname{Pd}(\mathrm{II})$ signals decreased sharply beyond the centrifugation time of $10 \mathrm{~min}$ as can be seen from Figure 5. The optimum time for this process was chosen as $3 \mathrm{~min}$.

\section{Effect of foreign ions}

The influences of some alkali and alkaline earth elements, and some cations and anions on the recoveries of palladium ions by the presented system were investigated.
The interference was due to the competition of other metal ions for the chelating agent and their subsequent coextraction with palladium. In these experiments, solutions containing $1 \mathrm{mg} \mathrm{L}^{-1} \mathrm{Pd}$ and the interfering species were treated according to the recommended procedure. The tolerance limits of the coexisting ions are defined as the largest amount making the recovery of Pd less than 95\%. The results are given in Table 1. Large amounts of alkaline and alkaline earth metal ions had no interference with the DLLME method under the optimum conditions due to probably low stabilities of their $2,2^{\prime}$-furyldioxime complexes. These metal ions did not show any interfering effect for the studied levels for the determination of palladium in various samples.

Table 1. The influences of some ions on the microextraction of Pd(II) $(\mathrm{n}=3)$

\begin{tabular}{|c|c|c|c|}
\hline Ions & Added as & $\begin{array}{l}\text { Concentration / } \\
\quad\left(\mathrm{mg} \mathrm{L}^{-1}\right)\end{array}$ & $\begin{array}{c}\text { Recovery / } \\
(\%)\end{array}$ \\
\hline $\mathrm{Na}^{+}$ & $\mathrm{NaNO}_{3}$ & 20,000 & $100 \pm 1^{\mathrm{a}}$ \\
\hline $\mathrm{K}^{+}$ & $\mathrm{KNO}_{3}$ & 5,000 & $100 \pm 1$ \\
\hline $\mathrm{Ca}^{2+}$ & $\mathrm{Ca}\left(\mathrm{NO}_{3}\right)_{2} \cdot 4 \mathrm{H}_{2} \mathrm{O}$ & 5,000 & $100 \pm 1$ \\
\hline $\mathrm{Mg}^{2+}$ & $\mathrm{Mg}\left(\mathrm{NO}_{3}\right)_{2} \cdot 6 \mathrm{H}_{2} \mathrm{O}$ & 5,000 & $98 \pm 1$ \\
\hline $\mathrm{Zn}^{2+}$ & $\mathrm{Zn}\left(\mathrm{NO}_{3}\right)_{2}$ & 50 & $98 \pm 1$ \\
\hline $\mathrm{Fe}^{3+}$ & $\mathrm{Fe}\left(\mathrm{NO}_{3}\right)_{3} \cdot 6 \mathrm{H}_{2} \mathrm{O}$ & 10 & $98 \pm 1$ \\
\hline $\mathrm{Cu}^{2+}$ & $\mathrm{Cu}\left(\mathrm{NO}_{3}\right)_{2} \cdot 4 \mathrm{H}_{2} \mathrm{O}$ & 10 & $100 \pm 1$ \\
\hline $\mathrm{Cl}^{-}$ & $\mathrm{NaCl}$ & 10,000 & $99 \pm 1$ \\
\hline $\mathrm{SO}_{4}^{2-}$ & $\mathrm{Na}_{2} \mathrm{SO}_{4}$ & 5,000 & $97 \pm 1$ \\
\hline $\mathrm{H}_{2} \mathrm{PO}_{4}^{-}$ & $\mathrm{NaH}_{2} \mathrm{PO}_{4} \cdot 2 \mathrm{H}_{2} \mathrm{O}$ & 5,000 & $101 \pm 2$ \\
\hline
\end{tabular}

${ }^{\mathrm{a} A v e r a g e} \pm$ standard deviation.

The influences of some cations and anions which are present in real samples as common matrix components (like $\mathrm{Na}^{+}, \mathrm{K}^{+}, \mathrm{Ca}^{2+}, \mathrm{Mg}^{2+}, \mathrm{Zn}^{2+}, \mathrm{Fe}^{3+}, \mathrm{Cu}^{2+}, \mathrm{Cl}^{-}, \mathrm{SO}_{4}{ }^{2-}, \mathrm{H}_{2} \mathrm{PO}_{4}^{-}$) on the recovery of $\mathrm{Pd}(\mathrm{II})$ ions were investigated.

\section{Evaluation of method performance}

For the purpose of quantitative analysis, a calibration curve for Pd with concentrations ranging over six orders was obtained by spiking the standards directly into deionized water and extracted under the optimum conditions. Calibration curve without preconcentration was $\mathrm{A}=0.0035 \mathrm{C}_{\mathrm{Pd}}+0.010\left(\mathrm{r}^{2}=0.9991\right)$, while it was $\mathrm{A}=0.0164 \mathrm{C}_{\mathrm{Pd}}+0.0076\left(\mathrm{r}^{2}=0.9996\right)$ after applying the preconcentration procedure, where $\mathrm{A}$ is absorbance and $\mathrm{C}_{\mathrm{Pd}}$ is palladium concentration. Linearity was observed over the range 1-48 $\mu \mathrm{g} \mathrm{L}^{-1}$ before applying the preconcentration procedure. Also, this calibration range corresponds to $0.25-12 \mathrm{mg} \mathrm{L}^{-1}$ after the application of 
the procedure. The limit of detection (LOD), based on 3s, was $0.04 \mu \mathrm{g} \mathrm{L}^{-1}$. The preconcentration factor of 250 was obtained. Table 2 shows the characteristic data of the present method compared with those reported in the literature. By flame microsampling technique, the consumption of the extractant phase was minimized and the enrichment factor of the microextraction technique was improved. A comparative data including recent studies made for the determination of $\mathrm{Pd}(\mathrm{II})$ in various samples is given in Table 2. As can be seen from the Table, the present method has some advantages compared to the most of the others from the point of view of the limit of detection,

Table 2. Comparison of the results of the proposed method with the other published works for the determination of palladium

\begin{tabular}{|c|c|c|c|c|c|c|c|c|}
\hline $\begin{array}{l}\text { Preconcentration } \\
\text { method }\end{array}$ & Samples & Technique & $\begin{array}{c}\text { Number of steps } \\
\text { and time/min }\end{array}$ & Amount of reagent/solvent & $\begin{array}{l}\mathrm{LOD} / \\
\left(\mu \mathrm{g} \mathrm{L} \mathrm{L}^{-1}\right)\end{array}$ & $\begin{array}{c}\mathrm{RSD} / \\
(\%)\end{array}$ & $\mathrm{PF}$ & Reference \\
\hline DLLME & Water samples & FAAS & 7 and 5 & $\begin{array}{c}0.45 \mathrm{mg} \text { thioridazine/ } \\
1.5 \mathrm{~mL} \text { of ethanol }+ \\
150 \mu \mathrm{L} \text { of } \mathrm{CHCl}_{3}\end{array}$ & 90 & $0.7(\mathrm{n}=5)$ & 45.7 & 10 \\
\hline SFODME $^{\mathrm{a}}$ & $\begin{array}{l}\text { Water samples, } \\
\text { synthetic } \\
\text { samples }\end{array}$ & FAAS & 7 and 15 & $\begin{array}{c}5 \mu \mathrm{L} \text { of } \mathrm{APDC}(0.37 \%, \mathrm{~m} / \mathrm{v}) / \\
35 \mu \mathrm{L} \text { of } 1 \text {-undecanol }\end{array}$ & 0.6 & 2 & 49.9 & 12 \\
\hline SF-EX-FIA ${ }^{b}$ & $\begin{array}{l}\text { Airborne } \\
\text { particulate } \\
\text { matter, } \\
\text { automobile } \\
\text { catalysts }\end{array}$ & $\begin{array}{l}\text { Spectro- } \\
\text { photometry }\end{array}$ & - & - & 7 & $<3.5$ & - & 19 \\
\hline $\mathrm{CPE}$ & Mine stone & ICP-OES & $\begin{array}{l}8 \text { and } 15 \text { (only } \\
\text { water bath) }\end{array}$ & $\begin{array}{c}1 \% \mathrm{~m} / \mathrm{v} O, O \text {-diethyl dithio } \\
\text { phosphate/Triton X-114 } \\
(0.05 \%, \mathrm{~m} / \mathrm{v})\end{array}$ & 0.3 & $<5$ & 20 & 23 \\
\hline DLLME & Water samples & GFAAS & 5 and 5 & $\begin{array}{c}0.10 \mathrm{mg} \mathrm{mL}^{-1} \mathrm{DDTC} / \\
0.5 \mathrm{~mL} \text { of ethanol }+ \\
40 \mu \mathrm{L} \text { of } \mathrm{CCl}_{4}\end{array}$ & 2400 & 4.3 & 156 & 33 \\
\hline SPE & $\begin{array}{l}\text { Nickel alloy, } \\
\text { anode slime, } \\
\mathrm{CoCl}_{2} \text { solution }\end{array}$ & FI-FAAS ${ }^{c}$ & - & - & 200 & 0.3 & - & 45 \\
\hline SPE & $\begin{array}{c}\text { Geological } \\
\text { sample, anode } \\
\text { slime, nickel } \\
\text { alloy }\end{array}$ & FI-FAAS & - & - & 26 & 2 & - & 46 \\
\hline SPE & $\begin{array}{l}\text { Automobile } \\
\text { catalysts }\end{array}$ & FI-ICP-OES ${ }^{\mathrm{d}}$ & - & - & 0.02 & - & 35 & 47 \\
\hline SPE & $\begin{array}{l}\text { Spiked natural } \\
\text { waters }\end{array}$ & ICP-OES & - & - & 0.2 & 3.2 & 100 & 48 \\
\hline DLLME & $\begin{array}{l}\text { Alloy, road dust } \\
\text { sample }\end{array}$ & FAAS & 7 and 3 & $\begin{array}{c}\text { Ligandless } / 2 \mathrm{~mL} \text { of ethanol + } \\
15.0 \mu \mathrm{L} \text { of } \mathrm{CCl}_{4}\end{array}$ & 1.4 & 1.5 & - & 49 \\
\hline M-CIAME & $\begin{array}{l}\text { Sea water, tea } \\
\text { and biological } \\
\text { samples }\end{array}$ & $\begin{array}{c}\text { Spectro- } \\
\text { photometry }\end{array}$ & 6 and 5 & $\begin{array}{c}5.2 \times 10^{-6} \mathrm{~mol} \mathrm{~L}^{-1} \text { of Michler } \\
\text { thioketone } / 60 \mu \mathrm{L}\left[\mathrm{Hmim}_{[}\right]\left[\mathrm{BF}_{4}\right]+ \\
1.2 \mathrm{~mL} \mathrm{NaPF}_{6}\end{array}$ & 0.2 & 1.7 & 97 & 50 \\
\hline DLLME & $\begin{array}{l}\text { Roadside soil, } \\
\text { tap water, } \\
\text { mineral water }\end{array}$ & GFAAS & 5 and 2 & $\begin{array}{c}1.0 \times 10^{-3} \mathrm{~mol} \mathrm{~L}^{-1} \\
\text { 2-amino-1-cyclohexene-1- } \\
\text { dithiocarboxylic acid/800 } \mu \mathrm{L} \\
\text { of acetone }+40 \mu \mathrm{L} \text { of } \mathrm{CCl}_{4}\end{array}$ & 0.007 & 4.2 & 350 & 51 \\
\hline DLLME & $\begin{array}{l}\text { Reference } \\
\text { materials: } \\
\text { soil and ore }\end{array}$ & GFAAS & 7 and 5 & $\begin{array}{l}0.05 \mathrm{mg} \mathrm{mL}{ }^{-1} \mathrm{DDTC} / 0.5 \mathrm{~mL} \text { of } \\
\text { methanol }+48 \mu \mathrm{L} \text { of } \mathrm{CCl}_{4}\end{array}$ & 0.0076 & 4.5 & 96 & 52 \\
\hline DLLME & $\begin{array}{l}\text { Real and } \\
\text { synthetic } \\
\text { samples }\end{array}$ & FO-LADS ${ }^{\mathrm{f}}$ & 5 and 2 & $\begin{array}{c}1 \times 10^{-5} \mathrm{~mol} \mathrm{~L}{ }^{-1} \mathrm{PAN} / 0.40 \mathrm{~mL} \\
\text { ethanol }+70 \mu \mathrm{L} \text { of } \\
1,2 \text {-dichlorobenzene }\end{array}$ & 0.25 & $<4$ & 162 & 53 \\
\hline DLLME & $\begin{array}{l}\text { Converter, anode } \\
\text { slime, road } \\
\text { sediment, water } \\
\text { sample }\end{array}$ & FAAS & 5 and 3 & $\begin{array}{c}2,2^{\prime} \text {-furyldioxime }(0.1 \mathrm{~mL} \text { of } \\
0.1 \%) / 0.4 \mathrm{~mL} \text { of methanol }+100 \\
\mu \mathrm{L} \text { of } \mathrm{CHCl}_{3}\end{array}$ & 0.04 & $1.1(\mathrm{n}=8)$ & 250 & This work \\
\hline
\end{tabular}

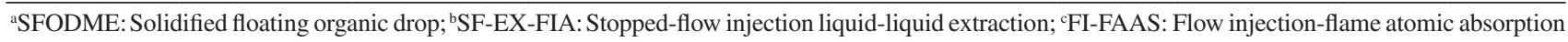
spectrometry; ${ }^{\mathrm{d}} \mathrm{FI}-\mathrm{ICP}-\mathrm{OES}$ : Flow injection-inductively coupled plasma-optical emission spectrometry; ${ }^{\mathrm{e}} \mathrm{M}$-CIAME: Modified cold-induced aggregation microextraction; ${ }^{\mathrm{f}} \mathrm{FO}-\mathrm{LADS}$ : Fiber optic-linear array detection spectrophotometry. 
relative standard deviation and high preconcentration factor values.

\section{Accuracy and precision}

The recovery studies for palladium(II) were performed in tap, sea and converter samples. The known amounts of palladium were spiked to the sample solutions in order to estimate the accuracy of the presented procedure (Table 3 ). Good agreement was obtained between the added and found analyte contents using the recommended procedure.

Table 3. The determination of Pd(II) in catalytic converter, tap water, sea water samples and certified reference material after the application of the presented procedure $(n=3)$

\begin{tabular}{lccc}
\hline Sample & Added & Found & $\begin{array}{c}\text { Recovery / } \\
(\%)\end{array}$ \\
\hline Catalytic converter / & - & $1150 \pm 13^{\mathrm{a}}$ & - \\
$\left(\mu \mathrm{g} \mathrm{g}^{-1}\right)$ & 1000 & $2142 \pm 24$ & $99 \pm 2$ \\
Tap water $/\left(\mathrm{mg} \mathrm{L}^{-1}\right)$ & - & - & - \\
& 5.0 & $5.03 \pm 0.01$ & $100 \pm 1$ \\
Sea water / $\left(\mathrm{mg} \mathrm{L}^{-1}\right)$ & - & - & - \\
& 5.0 & $4.95 \pm 0.08$ & $99 \pm 1$ \\
$\mathrm{CDN}-\mathrm{PGMS}-10 /$ & Certified value / & $11.10 \pm 0.10$ & $101 \pm 1$ \\
$\left(\mu \mathrm{g} \mathrm{g}^{-1}\right)$ & $10.99 \pm 0.73$ & & \\
\hline
\end{tabular}

${ }^{\mathrm{a}}$ Average \pm standard deviation.

To verify the accuracy of the proposed method, the Pd content of the certified reference material (CDN-PGMS-10) was determined by the proposed method. As can be seen in Table 3, the obtained results were in good agreement with the reference value.

The precision of the method was found to be $1.1 \%$ as the relative standard deviation by analyzing catalytic converter samples ( $\left.\overline{\mathrm{x}} \pm \mathrm{s}: 1142 \pm 13 \mu \mathrm{g} \mathrm{g}^{-1}, \mathrm{n}=8\right)$.

\section{Analysis of samples}

The proposed method was successfully applied to the determination of Pd(II) in catalytic converter, anode slime and road sediment samples (see Table 4).

Table 4. The concentration of $\mathrm{Pd}(\mathrm{II})$ in the various environmental samples $(\mathrm{n}=3)$

\begin{tabular}{lc}
\hline Sample & Pd content $^{\mathrm{a}} /\left(\mu \mathrm{g} \mathrm{g}^{-1}\right)$ \\
\hline Catalytic converter 1 & $3280 \pm 51$ \\
Catalytic converter 2 & $3413 \pm 47$ \\
Catalytic converter 3 & $1142 \pm 13$ \\
Anode slime & $1.98 \pm 0.01$ \\
Road sediment 1 & $0.25 \pm 0.01$ \\
Road sediment 2 & $0.66 \pm 0.01$ \\
\hline
\end{tabular}

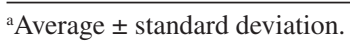

\section{Conclusions}

A new DLLME method combined with FAAS has been proposed for the determination of Pd in catalytic converter, anode slime, road sediment and water samples. The method is simple, rapid, low toxicity, highly sensitive, reproducible, inexpensive, and has a lower limit of detection and higher preconcentration factor over other methods reported in the references. Especially, the sample preparation time and consumption of toxic organic solvents are minimized in this method without affecting the sensitivity of the method. Also the use of FAAS as a detection system has low cost and operational facilities.

\section{References}

1. EPOW - European Pathway to Zero Waste; Protecting and Recovering Critical Raw Materials, Oakdene Hollins Ltd.: Aylesbury, England, 2011. http://www.environment-agency. gov.uk/EPOW accessed in November 2011.

2. Dimitrova, B.; Benkhedda, K.; Ivanova, E.; Adams, F.; Can. J. Anal. Sci. Spectrosc. 2004, 49, 347.

3. Tilch, J.; Schuster, M.; Schwarzer, M.; Fresenius J. Anal. Chem. 2000, 367, 450.

4. Boch, K.; Schuster, M.; Risse, G.; Schwarzer, M.; Anal. Chim. Acta 2002, 459, 257.

5. Kovacheva, P.; Djingova, R.; Anal. Chim. Acta 2002, 464, 7.

6. Patel, K. S.; Sharma, P. C.; Hoffman, P.; Fresenius J. Anal. Chem. 2000, 367, 738.

7. Krishna, M. V.; Ranjit, M.; Chandrasekaran, K.; Venkateswarlu, G.; Karunasagar, D.; Talanta 2009, 79, 1454.

8. Bruzzoniti, M. C.; Mucchino, C.; Tarasco, E.; Sarzanini, C.; J. Chromatogr., A 2003, 1007, 93.

9. Nakajima, J.; Ohno, M.; Chikama, K.; Seki, T.; Oguma, K.; Talanta 2009, 79, 1050.

10. Kokya, T. A.; Farhadi, K.; J. Hazard. Mater. 2009, 169, 726.

11. Jamali, M. R.; Assadi, Y.; Shemirani, F.; Niasari, M. S.; Talanta 2007, 71, 1524.

12. Mohamadi, M.; Mostafavi, A.; Talanta 2010, 81, 309.

13. Gholivand, M. B.; Nozari, N.; Talanta 2000, 52, 1055.

14. Ensafi, A. A.; Keyvanfard, M.; Spectrochim. Acta, Part A 2002, 58, 1567.

15. Shemirani, F.; Kozani, R. R.; Jamali, M. R.; Assadi, Y.; Hosseini, M. R. M.; Int. J. Environ. Anal. Chem. 2006, 86, 1105.

16. Karthikeyan, J.; Parameshwara, P.; Shetty, A. N.; Shetty, P.; Indian J. Chem. Technol. 2006, 13, 484.

17. Gòmez, M. B.; Gòmez, M. M.; Palacios, M. A.; J. Anal. At. Spectrom. 2003, 18, 80.

18. Dong, Y.; Gai, K.; Bull. Korean Chem. Soc. 2005, 26, 943.

19. Anthemidis, A. N.; Themelis, D. G.; Stratis, J. A.; Talanta 2001, 54, 37. 
20. Rastegarzadeh, S.; Pourreza, N.; Kiasat, A. R.; Yahyavi, H.; Microchim. Acta 2010, 170, 135.

21. Wołowicz, A.; Hubicki, Z.; Solvent Extr. Ion Exch. 2010, 28 , 124.

22. Tavakoli, L.; Yamini, Y.; Ebrahimzadeh, H.; Nezhadali, A.; Shariati, S.; Nourmohammadian, F.; J. Hazard. Mater. 2008, $152,737$.

23. Da Silva, M. A. M.; Frescura, V. L. A.; Curtius, A. J.; Spectrochim. Acta, Part B 2001, 56, 1941.

24. Miro, M.; Estela, J. M.; Cerda, V.; Curr. Anal. Chem. 2005, 1, 329.

25. Pereira, F. P.; Lavilla, I.; Bendicho, C.; Spectrochim. Acta, Part B 2009, 64, 1.

26. Anthemidis, A. N.; Adam, I. S. I.; Anal. Chim. Acta 2009, 632, 216.

27. Adam, I. S. I.; Anthemidis, A. N.; Talanta 2009, 77, 1160.

28. Paleologos, E. K.; Giokas, D. L.; Karayannis, M. I.; $\operatorname{Tr} A C$, Trends Anal. Chem. 2005, 24, 426.

29. Razaee, M.; Assadi, Y.; Hosseini, M. R. M.; Aghaee, E.; Ahmadia, F.; Berijani, S.; J. Chromatogr., A 2006, 1116, 1.

30. Anthemidis, A. N.; Ioannou, K. I. G.; Talanta 2009, 79, 86.

31. Jahromi, E. Z.; Bidari, A.; Assadi, Y.; Hosseini, M. R. M.; Jamali, M. R.; Anal. Chim. Acta 2007, 585, 305.

32. Li, S.; Cai, S.; Hu,W.; Chen, H.; Liu, H.; Spectrochim. Acta, Part B 2009, 4, 666.

33. Liang, P.; Zhao, E.; Li, F.; Talanta 2009, 77, 1854.

34. Jiang, H.; Qin, Y.; Hu, B.; Talanta 2008, 74, 1160.

35. Kocúrová, L.; Balogh, I. S.; Šandrejová, J.; Andruch, V.; Microchem. J. 2012, 102, 11.

36. Zhang, P.; Shi, Z. G.; Yu, Q. W.; Feng, Y. Q.; Talanta 2011, 83, 1711.

37. Farajzadeh, A.; Seyedi, S. E.; Shalamzari, M. S.; Bamorowat, M.; J. Sep. Sci. 2009, 32, 3191.
38. Hashemi, P.; Beyranvand, S.; Mansur, R. S.; Ghiasvand, A. R.; Anal. Chim. Acta 2009, 655, 60.

39. Saleh, A.; Yamini, Y.; Faraji, M.; Rezaee, M.; Ghambarian, M.; J. Chromatogr., A 2009, 1216, 6673.

40. Zhang, P.; Shi, Z. G.; Feng, Y. Q.; Talanta 2011, 85, 2581.

41. Bidari, A.; Ganjali, M. R.; Assadi, Y.; Norouzi, P.; Anal. Methods 2011, 3, 724.

42. Elçi, L.; Kartal, Ş.; Ülgen, A.; Doğan, M.; Doğan, P.; Turk. J. Chem. 1990, 14, 294.

43. Lukevics, E.; Pudova, O. A.; Khimiya Geterotsiklicheskikh Soedinenii 1997, 33, 154.

44. Templeton, D. H.; Watt, G. W.; Garner, C. L.; J. Am. Chem. Soc. 1943, 65, 1608.

45. Liu, P.; Pu, Q.; Su, Z.; J. Anal. Chem. 2005, 60, 1023.

46. Pu, Q.; Liu, P.; Sun, Q.; Su, Z.; Microchim. Acta 2003, 43, 45.

47. Muzikar, M.; Fontas, C.; Hidalgo, M.; Havel, J.; Salvado, V.; Talanta 2006, 70, 1081.

48. Birinci, E.; Gülfen, M.; Aydın, A. O.; Hydrometallurgy 2009, 95, 15.

49. Mohammadi, S. Z.; Afzali, D.; Taher, M. A.; Baghelani, Y. M.; Microchim. Acta 2010, 168, 123.

50. Vaezzadeh, M.; Shemirani, F.; Majidi, B.; Food Chem. Toxicol. 2010, 48, 1455.

51. Shamsipur, M.; Ramezani, M.; Sadeghi, M.; Microchim. Acta 2009, 166, 235.

52. Liang, P.; Zhao, E.; Microchim. Acta 2011, 174, 153.

53. Shokoufi, N.; Shemirani, F.; Assadi, Y.; Anal. Chim. Acta 2007, 597,349 .

Submitted: November 23, 2011

Published online: May 3, 2012 